\title{
ИЗУЧЕНИЕ МЕХАНИЗМОВ РАСШИРЕНИЯ СПЕКТРА ЦИТОТОКСИЧНОСТИ ПЕГИЛИРОВАННЫХ ЛИПОСОМАЛЬНЫХ СИСТЕМ ДОСТАВКИ ПРОТИВООПУХОЛЕВЫХ ПРЕПАРАТОВ МЕТОДОМ СПИНОВЫХ ЗОНДОВ
}

\author{
${ }^{1}$ Ведуший научный сотрудник Л. В. Иванов, \\ ${ }^{2}$ Дочент А. В. Щербак, \\ ${ }^{3}$ Профессор В. Г. Кравченко, \\ ${ }^{4}$ Профессор Л. В. Деримедведь, \\ ${ }^{4}$ Профессор Э. В. Супрун \\ ${ }^{1}$ Институт химии поверхности НАН Украины, \\ ${ }^{2}$ Харьковская государственная зооветеринарная академия, \\ ${ }^{3}$ Украинская медицинская стоматологическая академия, \\ ${ }^{4}$ Национальный фармачевтический университет
}

DOI: https://doi.org/10.31435/rsglobal_ws/30062019/6573

\section{ARTICLE INFO}

Received: 30 April 2019

Accepted: 21 June 2019

Published: 30 June 2019

\section{KEYWORDS}

cytotoxicity,

pegylated liposomal delivery systems, microviscosity of membrane lipids, spin probe method, hydrophobic interaction.

\begin{abstract}
Pegylated liposomal anticancer drugs, in particular, doxorubicin have an expansion of the spectrum of toxicity. To study the mechanisms of influence of polyethylene glycol (PEG) on the structure of cell membranes, the sensitive biophysical method of spin probes was used. Using the spin probe method, it has been shown that in the presence of an increased prothrombin blood index, increased blood viscosity and a high density of red blood cells and other blood components, large and long fragments of PEG molecules located on the surface of pegylated liposomal delivery systems can effectively interact with the membranes of neighboring cells. The list of even these possible effects, which were determined and described by us in experiments for bovine serum albumin, liposomes, erythrocytes and skin tissue, suggests that the expansion of the spectrum of the specific toxicity of pegylated liposomes may be directly or indirectly associated with the mechanisms of action of PEG on proteins and cell membranes.
\end{abstract}

Citation: Л. В. Иванов, А. В. Щербак, В. Г. Кравченко, Л. В. Деримедведь, Э. В. Супрун. (2019) Izuchenie Mekhanizmov Rasshireniya Spektra Citotoksichnosti Pegilirovannyh Liposomal'nyh Sistem Dostavki Protivoopuholevyh Preparatov Metodom Spinovyh Zondov. World Science. 6(46), Vol.3. doi: 10.31435/rsglobal_ws/30062019/6573

Copyright: () 2019 Л. В. Иванов, А. В. Щербак, В. Г. Кравченко, Л. В. Деримедведь, Э. В. Супрун. This is an open-access article distributed under the terms of the Creative Commons Attribution License (CC BY). The use, distribution or reproduction in other forums is permitted, provided the original author(s) or licensor are credited and that the original publication in this journal is cited, in accordance with accepted academic practice. No use, distribution or reproduction is permitted which does not comply with these terms.

Введение. В последнее время интерес исследователей в области медицины, биологии и фармации привлекают полиэтиленгликоли (полиэтиленоксиды) с различной молекулярной массой. Рядом исследований было установлено, что конъюгация различных лекарственных препаратов, систем доставки лекарственных веществ (ЛВ) в организм или углеродных наночастиц различной структуры с полиэтиленгликолем (ПЭГ, PEG) большой молекулярной массы приводит к повышению биосовместимости этих объектов с клетками организма [1-3, 22]. Так, в работе Murakami T. и др. [1] описана процедура диспергирования окисленных одностенных углеродных нанохорнов (oxSWNHs) в водном растворе с использованием конъюгата полиэтиленгликоль-доксорубицин (PEG-DXR). Полученный комплекс PEG-DXRoxSWNH способен проходить через хроматографическую среду на основе декстрана (Sephadex 
G25), уравновешенную водой, то есть конъюгат PEG-DXR придает oxSWNH диспергируемость в водном растворе. Эти результаты показывают, что разработанный метод может открыть путь для использования oxSWNHs в качестве клинически значимого в практике носителя лекарственного средства.

Гидрофобные одностенные углеродные нанохорны (SWNHs), диспергированные в водных средах путем нековалентной модификации их поверхности с молекулами конъюгата, состоят из полиэтиленгликоля (ПЭГ) и пептидных аптамеров (NHBP-1), которые специфически связываются с поверхностями ОСНХ [2]. Конъюгаты синтезировали путем связывания ПЭГ20000 и ПЭГ-5000 с N-концом NHBP-1 с получением 20PEG-NHBP и 5PEG-NHBP соответственно. Окисленные SWNH (oxSWNH), смешанные с 20PEG-NHBP или 5PEG-NHBP, хорошо диспергировали в воде и пропускали через гель-фильтрационную колонку. Диаметр комплекса oxSWNHs/20PEG-NHBP составляет примерно 210 нм.

Таким образом, комплекс CDDP-oxSWNHs/20PEG-NHBP, в котором цисплатин (CDDP), используемый для химиотерапии онкологических заболеваний, был загружен внутрь oxSWNHs, хорошо диспергирован, как в PBS, так и в культуральной среде и оказывал выраженное цитотоксическое действие против раковых клеток [2].

В некоторых исследованиях конъюгаты ПЭГ с фосфолипидами вводят в липосомальные системы доставки противоопухолевых препаратов, получая пегилированные липосомы пролонгированного действия, защищенные от действия макрофагов печени и селезенки. Ряд исследователей синтезируют конъюгаты ПЭГ с ферментами, белками и различными лекарственными веществами (ЛВ) и получают более эффективные препараты пролонгированного действия [3]. В табл. 1 приведены данные, свидетельствующие о значительном, в десятки раз, повышении периода полувыведения лекарственных препаратов нативных белков после пегилирования их макромолекул.

Таблица 1. Влияние пегилирования на период полувыведения нативных белков

\begin{tabular}{|c|c|c|c|c|}
\hline \multirow[b]{2}{*}{ Белок } & \multirow[b]{2}{*}{ Вид } & \multicolumn{2}{|c|}{ Период полужизни (час) } & \multirow{2}{*}{$\begin{array}{c}\text { Увеличение } \\
\text { периода } \\
\text { полужизни }\end{array}$} \\
\hline & & $\begin{array}{l}\text { Нативная } \\
\text { молекула }\end{array}$ & ПЕГ-конъюгат & \\
\hline Аденозиндезаминаза & Мышь & 0,5 & 28 & 56 \\
\hline Аспарагиназа & Человек & $20-72$ & $357-528$ & $7,3-17,7$ \\
\hline Интерферон- $\alpha_{2 в}$ & Человек & 4 & 40 & 10 \\
\hline Интерлейкин-2 & Крыса & 0,05 & 0,32 & 6.4 \\
\hline Стрептокиназа & Мышь & 0,07 & 0,33 & 4,7 \\
\hline Супероксиддисмутаза & Человек & 0,42 & 204 & 486 \\
\hline Уриказа & Человек & $3 \leq$ & 8 & $\geq 2,7$ \\
\hline
\end{tabular}

Данная работа посвящена исследованиям одного из типов нанокапсул - липосомам, которые выступают в качестве контейнера для доставки лекарственных средств. Мембрана липосом состоит из природных фосфолипидов, что и определяет ряд их качеств. Липосомы нетоксичны, хорошо подвергаются полной биодеградации, при определенных условиях хорошо поглощаются клетками; мембрана липосом может сливаться с клеточной мембраной, что приводит к внутриклеточной доставке находящихся в них веществ [4].

Поскольку размер наночастиц больше диаметра пор капилляров, то объем их распределения ограничивается компартаментом введения. Например, при внутривенном введении липосомы не выходят за пределы кровотока, то есть слабо проникают в органы и ткани. Последнее способствует резкому снижению токсического действия субстанций, ассоциируемых с наночастицами. С другой стороны, это свойство может служить основой для направленной доставки препаратов в злокачественные новообразования, поскольку региональные капилляры, как правило, сильно перфорированные (рис. 1). 

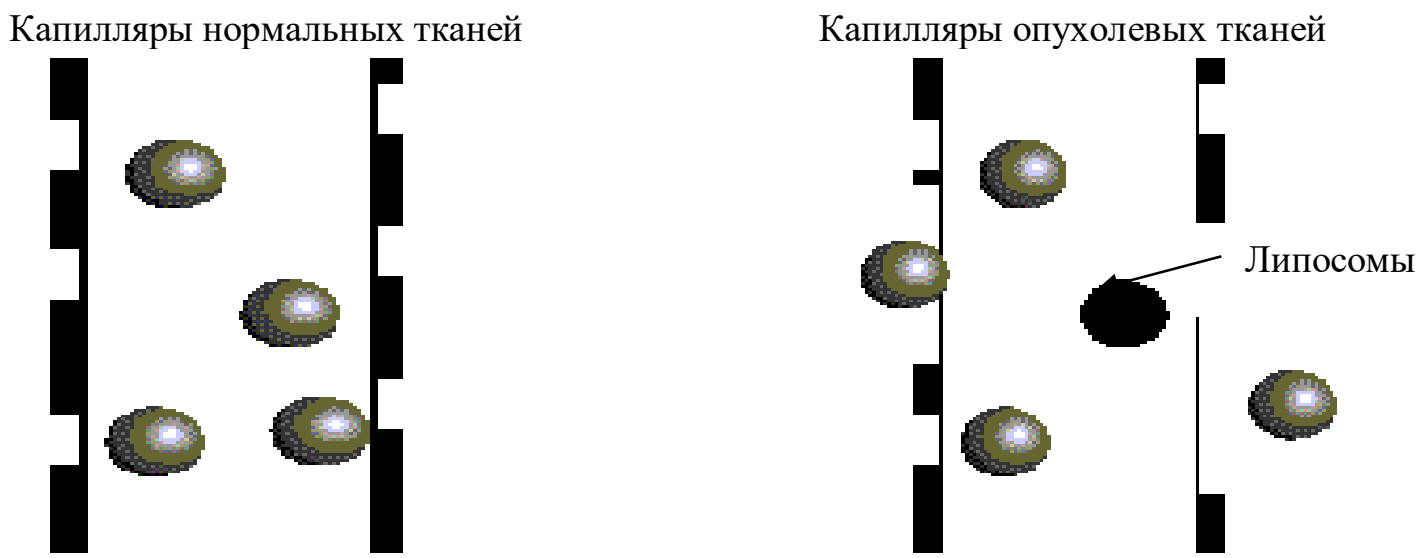

Рис. 1. Проницаемость капилляров для липосом. Липосомы проникают сквозь поры капилляров только в перфорированных капиллярах злокачественных новообразований.

Это способствует накоплению наночастиц в опухолевых тканях $[4,15]$. Данное явление получило название пассивного нацеливания, которое обусловлено особенностями ткани новообразования, в частности повышенной проницаемостью капилляров и нарушением циркуляции лимфы. Подобная фармакокинетика присуща большинству микро- и наночастиц, за исключением частиц размером 1-2 нм. Таким образом, существует две причины, вследствие которых липосомальные препараты противоопухолевого действия могут быть эффективны: уменьшение токсичности препаратов и пассивное нацеливание.

Один из ключевых вопросов, от которого зависят особенности технологии основных этапов создания липосомальных систем доставки (ЛСД), является вопрос о сродстве ЛВ к липидам мембран липосом и о характере распределения молекулы ЛВ между водой и мембраной (мембранотропные свойства ЛВ). Это связано с тем, что процесс и результат включения ЛВ в липосомы, диффузия ЛВ из липосом через мембрану наружу (истечение ЛВ), перенос ЛВ из липосом на мембраны клеток органа-мишени и быстрое распределение ЛВ в тканях органах-мишенях напрямую зависят от способности ЛВ взаимодействовать и солюбилизоваться в липидах мембран не только липосомальных средств доставки (ЛСД), но и в клетках-мишенях, например, в раковых клетках [5-7]. В состав липосом кроме фосфолипидов включают и холестерин, который уменьшает жидкостные свойства мембран липосом, после чего утечка многих ЛВ заметно уменьшается [8].

Липосомы, как и другие наночастицы, достаточно быстро захватываются ретикулоэндотелиальной системой (РЭС) селезенки и печени. Это происходит вследствие взаимодействия липосом с белками плазмы - опсонинами (в основном, компонентами комплемента). Опсонины «помечают» липосомы, делая их мишенями для клеток РЭС. Понятно, что увеличение времени их циркуляции в крови еще больше повышает эффективность липосомальных препаратов. С этой целью несколько лет назад было предложено модифицировать их поверхность полимерами с гибкой гидрофильной цепью, например, полиэтиленгликолем (ПЭГ-2000, ПЭГ-5000). Для этого используются специальные модифицированные липиды, например, фосфатидилэтаноламин, конъюгированный с ПЭГ $[9,10]$.

На рис. 2 представлена схема такой «стерически стабилизированной» липосомы, а на следующем рисунке (рис. 3) - результаты подобной модификации [4]. Как видно из приведенных рисунков, белки (в данном случае меченый родамином овальбумин) не могут добраться до поверхности липосом. Гибкие молекулы ПЭГ создают в примембранном области чрезмерное осмотическое давление. Липосомы как бы становятся невидимыми для клеток РЭС (отсюда и название «Stealth liposomes»). 


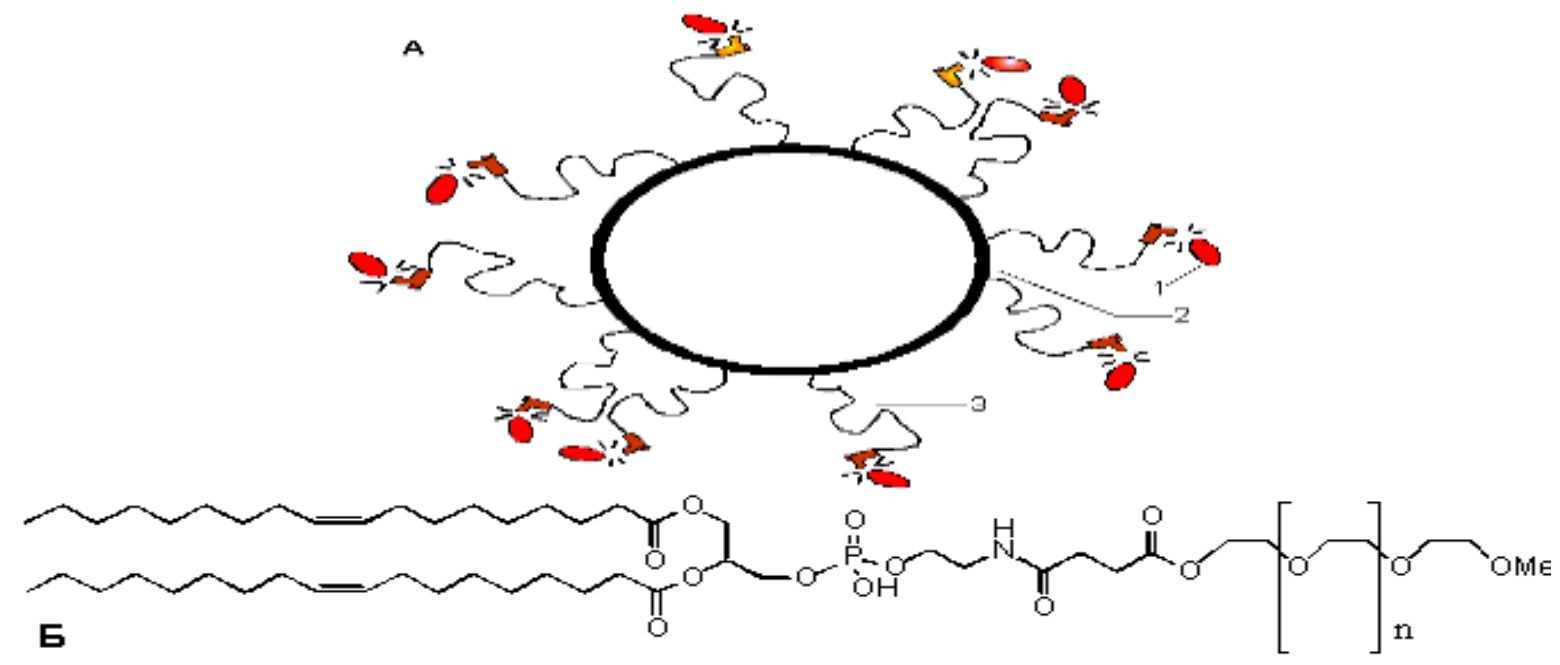

Рис. 2. A. - стерически стабилизированные липосомы (Stealth liposomes). Белки (1) не могут достичь поверхности липосом (2) из-за чрезмерного осмотического давления в примембранном пространстве, которое создается гибкими иепями (3) мобильных полимеров (например, ПЭГ). Б. - фосфатидилэтаноламин, конъюгированный с ПЭГ, используют для получения стерически стабилизированных липосом.

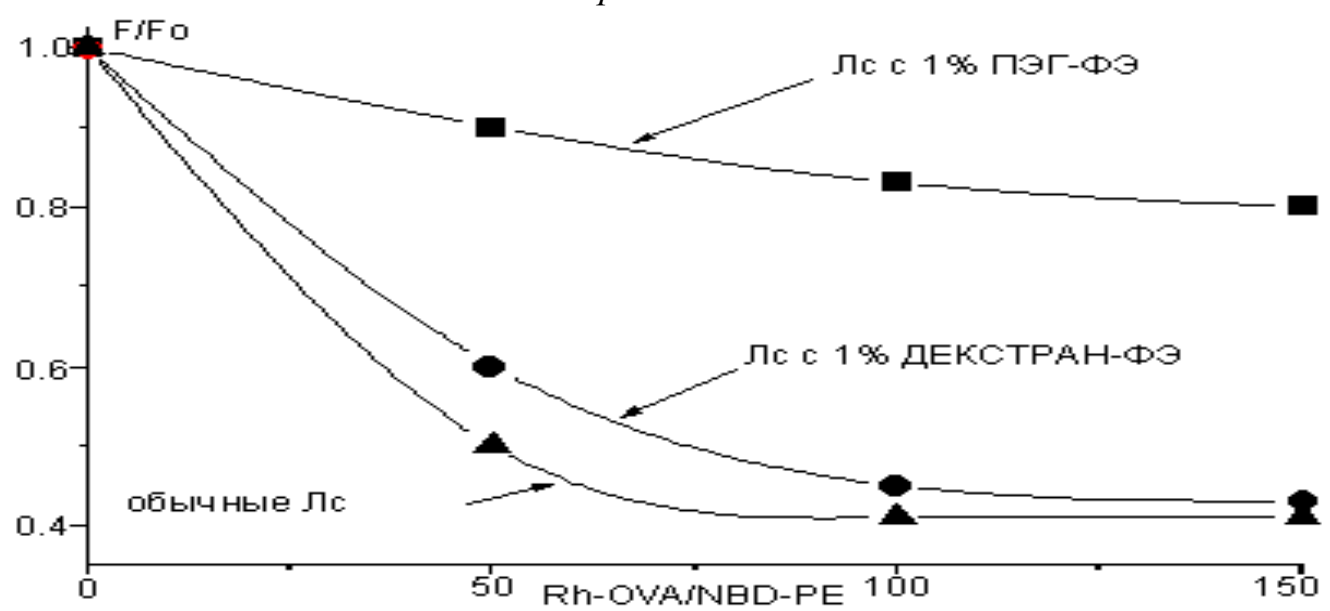

Рис. 3. Интенсивность тушения флуоресценции мембранного зонда (NBD-PE - флуоресцентный меченый фосфатидилэтаноламин белком, Rh-OVA-меченьй родамином овальбумин).

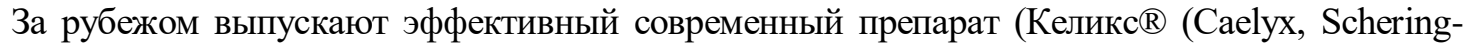
Plough, USA), представляющий собой пегилированный липосомальный доксорубицин, в котором слой полиэтиленгликоля окружает липосому, содержащую доксорубицин. Пегилирование предохраняет липосомы от распознавания и уничтожения ретикулоэндотелиальной системой, что по сравнению с традиционным доксорубицином (период полураспада составляет около 3 часов) повышает период полураспада в плазме крови до 55 часов. Размер липосом позволяет им проникать через дефекты капилляров ложа опухоли. Эта способность липосом в сочетании с длительным периодом полураспада облегчает доставку препарата (в частности, доксорубицина) непосредственно к новообразованию. Благодаря фармакокинетическому и фармакодинамическому профилю инкапсулированного доксорубицина в пегилированных липосомах создается высокий уровень препарата в опухолевой ткани по сравнению со здоровой, что значительно снижает кардиотоксические, гастроинтестинальные и другие побочные эффекты химиотерапевтических средств $[9,10]$. Увеличение фармакологической активности и изменение фармакокинетических свойств препаратов с ПЭГ (пролонгация) нередко сопровождается расширением их специфической токсичности препаратов. Так, в последнее время появились сообщения о возникновении аллергических и воспалительных реакций на ладонях рук и ногах у пациентов, принимавших пегилированные липосомальные противоопухолевые препараты, в частности, доксорубицин (Келикс) [11-14]. Эту форму токсичности пегилированных препаратов доксорубицина назвали 
ладонно-подошвенный синдром (ЛПС) как вариант проявления кожной токсичности. Аналогичные непегилированные липосомальные системы доставки этого побочного эффекта не имеют.

Также появились данные о расширении спектра специфической токсичности пегилированных липосомальных систем доставки (ЛСД). Очевидно, что причиной возникновения новых побочных эффектов у пациентов, принимающих пегилированные системы доставки противоопухолевых препаратов, могут быть длинные молекулы ПЭГ с большой молекулярной массой, которые свободно «выпирают» на поверхности липосом (длина около 25 нм - 250 ангстрем, что составляет четверть диаметра липосом). То есть на поверхности липосом находятся достаточно длинные и свободные фрагменты (хвосты) с ПЭГ, которые могут взаимодействовать с поверхностью мембран изолированных клеток или клеток тканей, находящихся поблизости в контакте с липосомальной системой доставки, и влиять на свойства другой мембраны, сродство различных веществ к поверхности мембран других клеток и т.п.

Целью работы было изучение механизмов влияния ПЭГ различной молекулярной массы на структуру ряда белков и мембран клеток методом спиновых зондов, то есть на белковом и мембранном уровне. Эти исследования позволят более детально изучить специфическую токсичность пегилированных ЛСД.

Конъюгат ЛВ с высокомолекулярным ПЭГ по способности взаимодействовать с белками и мембранами различных клеток можно приравнять к молекуле чистого ПЭГ такой же молекулярной массы. Изучая механизмы действия ПЭГ с разной массой на различные биообъекты (белки, мембраны клеток, свойства клеточных структур), можно попытаться объяснить механизмы повышения токсичности пегилированных липосом в сравнении с обычными. Для определения механизмов и закономерностей взаимодействия ПЭГ с биологическими объектами с помощью спиновых зондов мы изучали сродство ПЭГ к сывороточному альбумину (СА) мембран липосом, мембран эритроцитов, а также исследовали влияние ПЭГ на целостность мембран эритроцитов, микровязкость мембран эритроцитов, влияние ПЭГ на процессы дегидратации клеток ткани кожи крыс. Такое комплексное исследование позволит объяснить новые побочные реакции, возникающие у пациентов, принимающих пегилированные противоопухолевые препараты.

Материалы и методы. Взаимодействие ПЭГ с белками и мембранами нативных различных изолированных клеток и клеток тканей, отобранных у здоровых животных, изучали методом спиновых зондов [19,20]. Липосомы получали путем ультразвуковой обработки

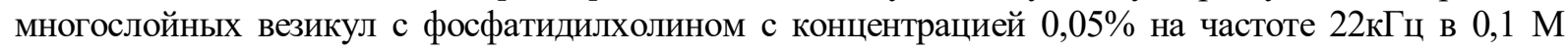
трис-буфере с $\mathrm{pH} 7,2$ по рекомендованной методике [16,17]. Эритроциты крови человека получали из эритромассы, отмытой от плазмы и стабилизирующего раствора центрифугированием, и разведенной изотоническим раствором $(0,15 \mathrm{M}$ трис-буфере с $\mathrm{pH} 7,2)$ в 2 раза. Для изучения сродства ЛВ и вспомогательных веществ с альбумином применяли электрофоретически однородный бычий сывороточный альбумин (САБ) фирмы «Calbiochem» и «Sigma chem.» (США), очищенный от жирных кислот. В работе использовали гидрофильные неводные растворители ПЭГ400, ПЭГ-1500 и ПЭГ-2000 фирмы «Merk», 1,2-пропиленгликоль (ПГ), глицерин.

Для изучения целостности мембран (табл. 2.) применяли водорастворимые стабильные нитроксильные радикалы: 2,2,6,6-тетраметил-4-окси-пиперидин-1-оксилы (1). Для изучения текучести липидов мембран использовали 1-оксилы-2,2,6,6-тетраметилпиперидин-амид пальмитиновой кислоты (5), для изучения связывания ПЭГ с САБ использовали спин меченый прогестерон: Прегна-4-ен-3,20-диок[17,16a-d]-2,2-диметилоксазолидин-нитроксид (4), или зонд 2 [17].

Таблица 2. Спиновые зонды

\begin{tabular}{|l|l|c|}
\hline $\mathbf{1}$ & \multicolumn{1}{|c|}{$\mathbf{2}$} & $\mathbf{3}$ \\
\hline 1 & Вода внеклеточная и & внутриклеточная \\
& &
\end{tabular}


Продолжение таблицы 2.

\begin{tabular}{|l|l|c|}
\hline 1 & \multicolumn{2}{|c|}{ Гидрофобные «карманы» } \\
\hline 2 & сывороточного альбумина & \\
\hline 3 & Липиды биомембран & \\
\hline 4 & Липиды биомембран & \\
\hline 5 & Липиды биомембран & \\
\hline
\end{tabular}

Получение спин меченых препаратов. Введение гидрофобных спиновых зондов 2-5 в суспензию эритроцитов, липосом, или раствора САБ осуществлялось добавлением водноспиртовых растворов зондов таким образом, чтобы конечная концентрация этанола составляла не более $0,5-1 \%$. Спиновые зонды были предоставлены И. Лихтенштейном и Р.И. Ждановым (Институт химической физики РАН). Для оценки вращающейся подвижности спинового зонда в исследуемых биообъектов использовали параметры $\mathrm{h} 0 / \mathrm{h}+1$ и $\mathrm{h} 0 / \mathrm{h}-1$ спектров электронного парамагнитного резонанса (ЭПР), пропорциональных времени корреляции вращающейся подвижности зонда, где $\mathrm{h} 0, \mathrm{~h}+1$ и $\mathrm{h}-1$ - интенсивности компонентов спектра с величиной магнитного квантового числа ядра $\mathrm{N}^{14}(\mathrm{M})$ соответственно равного $0,+1$ и -1 [18].

Эти параметры пропорциональны времени корреляции $\tau_{c}$ с вращающейся диффузии зонда и просто определяются с спектров ЭПР. Теория спектров ЭПР стабильных нитроксильные радикалы в растворе основана на модели Мак-Коннелла $[19,20]$ и связывает параметры спектра ЭПР спинового зонда с параметрами вращательного диффузии зонда время корреляции вращательной диффузии $\tau_{\mathrm{c}}$ :

$$
\begin{aligned}
& 1 / \tau_{\mathrm{c}(+1)}=2 \cdot 10^{8} /\left[\left(\mathrm{h}_{0} / \mathrm{h}_{+1}\right)^{1 / 2}-1\right] \Delta \mathrm{H}_{0} \text { сек }^{-1} \\
& 1 / \tau_{\mathrm{c}(-1)}=3,6 \cdot 10^{9} /\left[\left(\mathrm{h}_{0} / \mathrm{h}_{-1}\right)^{1 / 2}-1\right] \Delta \mathrm{H}_{0} \text { сек }^{-1}
\end{aligned}
$$

где: $\mathrm{H}_{\mathrm{o}}$ - ширина центральной компоненты в гауссах, $\mathrm{h}_{\mathrm{o}}, \mathrm{h}_{+1} \mathrm{i} \mathrm{h}_{-1}-$ интенсивности компонентов спектра ЭПР с магнитным квантовым числом ядра $\mathrm{N}^{14}(\mathrm{M}=-0,+1,-1)$ (рис.4); v-1/ $\tau_{\mathrm{c}}-$ величина, условно названая «частотой вращения» радикала [19]. 


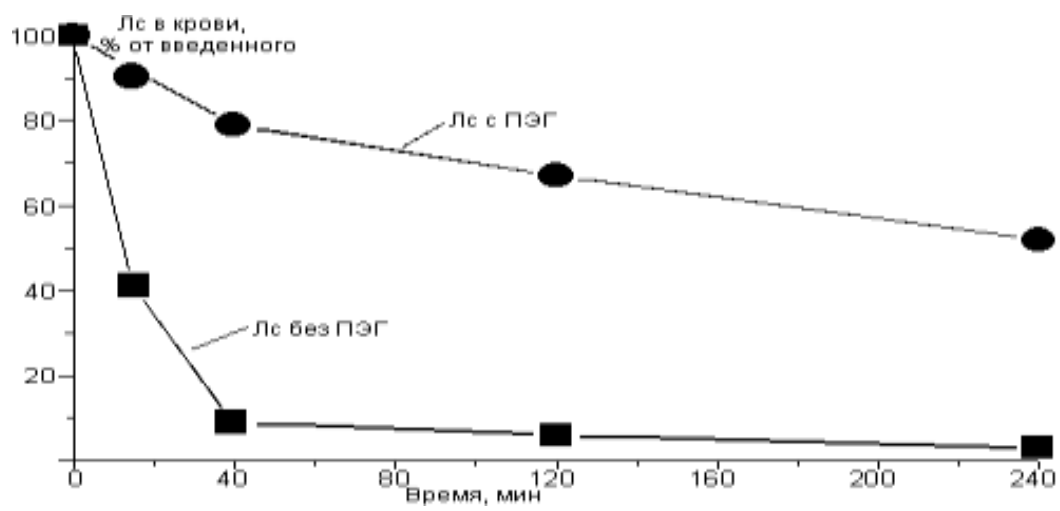

Рис. 4. Увеличение времени ииркуляции липосом, модифицированных ПЭГ (время циркуляции обычных (ЛС без ПЭГ) и стерически стабилизированных (ЛС с ПЭГ) липосом).

Однако на практике для оценки вращающейся подвижности спинового зонда в мембране или на белке часто используют параметры $h_{0} / h_{+1} ; h_{0} / h_{-1}$, которые пропорциональны $\tau_{c}$ и легко определяются со спектров ЭПР спинового зонда (рис. 5).

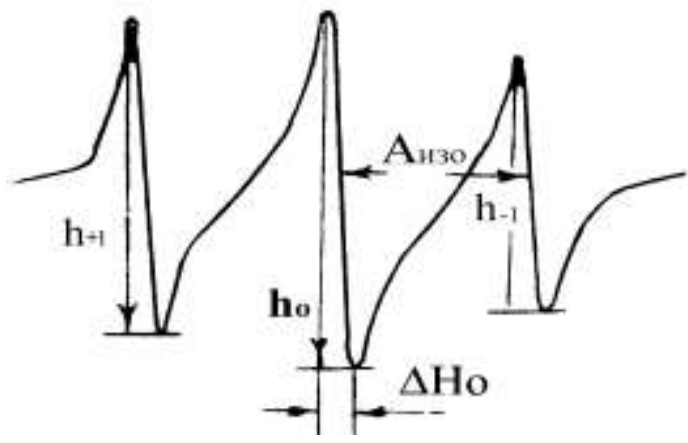

Рис. 5. Спектр ЭПР спинового зонда 1 в водно-глищериновой смеси; $H_{o}$ - иирина центральной компоненты в гаусса, $h_{o}, h_{+1} i h_{-1}-$ интенсивности компонентов спектра ЭПР с магнитным квантовым числом ядра $N^{14}(M)-0,+1 i-1 ; A_{i з 0}$ - изотропная константа HTC.

Следует отметить, что $\tau_{c}$ и вязкость связаны известным соотношением Стокса-Эйнштейна:

$$
\tau_{\mathrm{c}}=4 \pi \mathrm{a}^{3} \bullet \eta / 3 \kappa \mathrm{T}
$$

где: (ๆ) - вязкость среды, а - эффективный радиус спинового зонда.

В работе не определяли абсолютные значения вязкости липидов мембран, а оценивали относительные изменения микровязкости мембран эритроцитов в присутствии ПЭГ. Микровязкость мембраны эритроцитов является одним из важнейших структурных параметров мембран клеток. От нее напрямую зависит ферментативная активность мембранных ферментов, структура и работа ионных каналов, проницаемость мембран, биодоступность лекарственных веществ, проводимость нервного импульса.

Рис. 6 демонстрирует вытеснения гидрофобного спин-меченого прогестерона с гидрофобной пустоты САБ на поверхности САБ молекулами СЕГ-400 в результате эффективного связывания ПЭГ-400 с гидрофобной пустотой с помощью метиленовых $\mathrm{CH}_{2}-\mathrm{CH}_{2}$ групп.

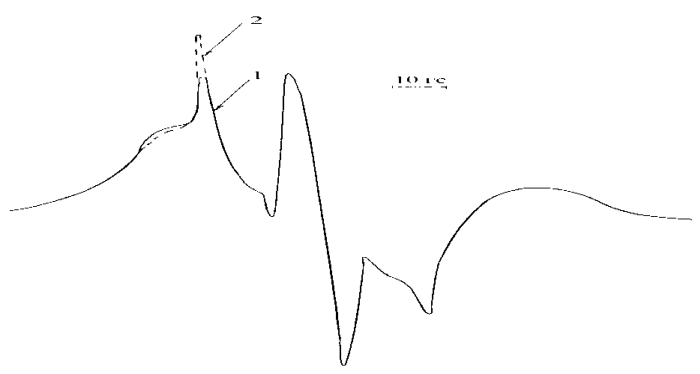

Рис. 6. Спектр ЭПР спинового зонда $4\left(5 \cdot 10^{-5} \mathrm{M}\right)$ в растворителе САБ $\left(10^{-4} \mathrm{M}\right): 1$ - контроль; 2 в присутствии ПЭГ-400 (20\%). 
Присутствие пегилированных ЛСД, например, в крови, наряду с макромолекулой сывороточного альбумина человека, основного переносчика экзогенных и эндогенных субстратов и лекарств может существенно разбалансировать систему транспорта необходимых субстратов в крови. Кроме того, подвижные действия гидрофобных ПЕГ-хвостов ЛСД могут приводить к связыванию хвостов ПЭГ с поверхностями других клеток (см. далее мембранотропные свойства ПЭГ) с токсичными последствиями для других клеток [17].

Спектр ЭПР меченого стероида в модельных клетках липосом является суперпозицией широкого, заторможенного спектра (зонд 3 в вязкой мембране) и малой части подвижного спектра зонда в воде (рис. 7).

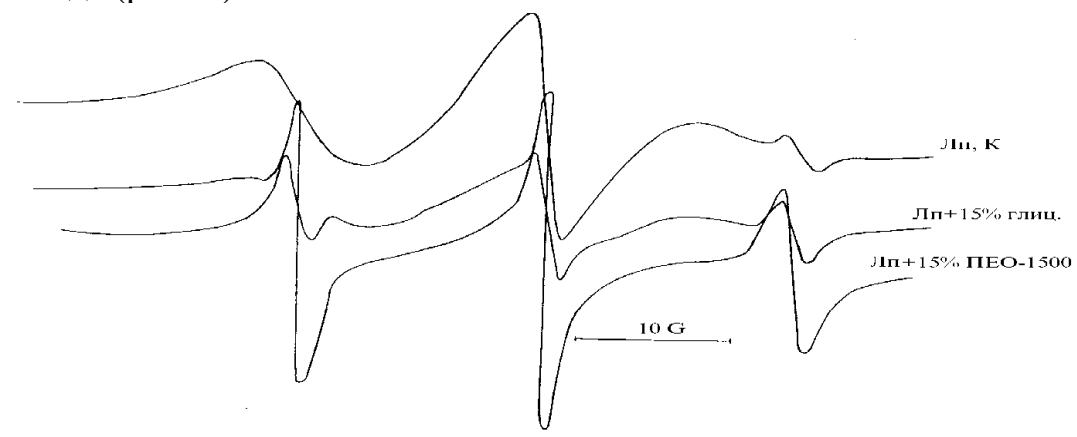

Рис. 7. Влияние глищерина (15\%) и ПЭГ-400 (15\%) на спектры ЭПР спинового зонда $3\left(5 \cdot 10^{-5} \mathrm{M}\right)$ в суспензии липосом.

Добавление $15 \%$ ПЭГ в липосомы приводит к резкому увеличению интенсивности узкой компоненты спектра вследствие вытеснения меченого стероида из мембраны в воду молекулами ПЭГ-1500. Это возможно только в случае значительного сродства ПЭГ-1500 к липидам мембран липосом. Таким образом, ПЭГ демонстрирует мембранотропные свойства.

Данные рис. 8 показывают, что присутствие в суспензии эритроцитов всего $3 \%$ ПЭГ1500 приводит к вытеснению из мембраны заметной части липофильного стероидного зонда.

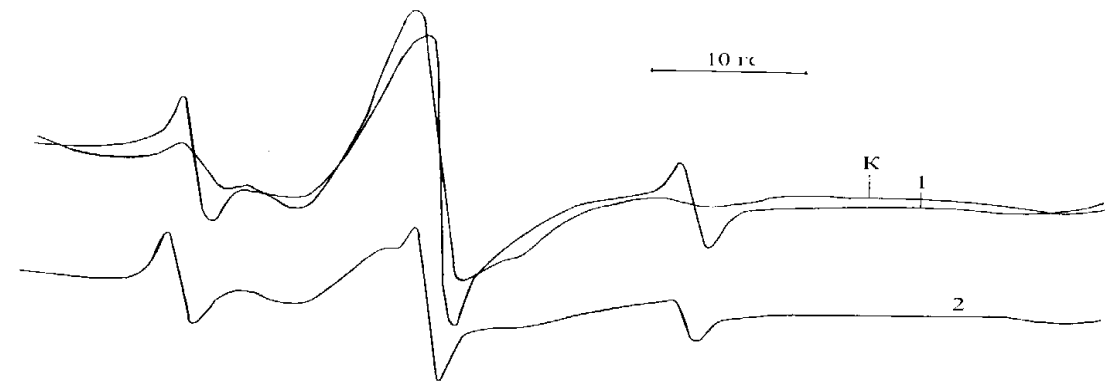

Рис. 8. Влияние глицерина (3\%) и ПЭГ-1500 (3\%) на спектры ЭПР спинового зонда $3\left(5 \cdot 10^{-5} \mathrm{M}\right)$ в суспензии эритроцитов: $K$ - контроль; 1 - эритроциты и ПЭГ-1500; 2 - эритроциты и глищерин.

Таким образом, хвосты пегилированных ЛСД могут взаимодействовать с поверхностью соседней клетки и экстрагировать из ее мембраны различные полезные липофильные вещества, нарушая поверхность мембраны и функционирование клетки. Следует отметить, что мембрана эритроцитов является наиболее прочной мембраной клеток организма, так как прошита трехмерной сеткой белка спектрина, поэтому другие мембраны клеток при аналогичных воздействиях могут пострадать больше [17].

Как было описано ранее, ПЭГ эффективно связываются с липидами мембран, что может привести к конформационным изменениям в липидном слое мембраны. Для детального изучения этих эффектов мы использовали зонд 5 , что является парамагнитной моделью амида пальмитиновой кислоты (табл. 3). Особенностью применения этого зонда является то, что он встраивается в мембраны практически как нативный мембранный липид, который осуществляет преимущественное вращения вокруг длинной оси молекулы $[19,20]$. Введение в суспензию эритроцитов парамагнитных ионов ферицианида калия или хлористого никеля не меняло спектра ЭПР зонда 5 в мембранах, что свидетельствует о недоступности нитроксильной головки спин-меченой пальмитиновой кислоты к воде в поверхностному липидному бислою мембран эритроцитов. 
Таблица 3. Зависимость параметров вращающейся диффузии спинового зонда 5 в мембранах эритроцитов от добавок гидрофильных неводных растворителей

\begin{tabular}{|c|c|c|c|c|c|c|}
\hline \multirow[t]{2}{*}{ Объект, растворители } & \multicolumn{3}{|c|}{$\begin{array}{c}\text { Параметры вращающейся } \\
\text { диффузии зонда }\end{array}$} & \multicolumn{3}{|c|}{$\begin{array}{c}\text { Изменение параметров } \\
\text { вращающейся диффузии зонда (в \%) }\end{array}$} \\
\hline & $\tau_{c}^{+} \cdot 10^{10}$ сек & $\tau$ - $_{\mathrm{c}} \cdot 10^{10}$ сек & $\varepsilon$ & $\tau_{\mathrm{c}}^{+} \cdot 10^{10}$ сек & $\tau-_{c} \cdot 10^{10}$ сек & $\varepsilon$ \\
\hline $\begin{array}{l}\text { Эритроциты в } \\
\text { физрастворе (контроль) }\end{array}$ & 7.3 & 10.1 & 0.040 & & & \\
\hline$+15 \%$ III & 9.6 & 10.8 & 0.053 & +31.5 & +6.9 & +32.5 \\
\hline $\begin{array}{l}\text { Эритроциты в } \\
\text { физрастворе (контроль) }\end{array}$ & 11.8 & 10.1 & 0.064 & & & \\
\hline$+15 \%$ IV & 12.7 & 11.5 & 0.066 & +7.6 & +13.9 & +3.1 \\
\hline $\begin{array}{l}\text { Эритроциты в } \\
\text { физрастворе (контроль) }\end{array}$ & 7.0 & 8.6 & 0.046 & & & \\
\hline$+15 \% \mathrm{~V}$ & 9.4 & 10.7 & 0.049 & +34.3 & +19.6 & +6.5 \\
\hline $\begin{array}{l}\text { Эритроциты в } \\
\text { физрастворе (контроль) }\end{array}$ & 8.8 & 9.5 & 0.034 & & & \\
\hline$+15 \%$ VI & 9.5 & 10.4 & 0.051 & +13.7 & +9.5 & +50.0 \\
\hline
\end{tabular}

Примечание: вспомогательные фармацевтические вещества: III-ПГ, IV-глицерин, V-ПЭГ-400, VI-ПЭГ-1500

Как было описано ранее, ПЭГ эффективно связываются с липидами мембран, что может привести к конформационным изменениям в липидном слое мембраны. Для детального изучения этих эффектов мы использовали зонд 5, что является парамагнитной моделью амида пальмитиновой кислоты (табл. 3). Особенностью применения этого зонда является то, что он встраивается в мембраны практически как нативный мембранный липид, который осуществляет преимущественное вращения вокруг длинной оси молекулы [19,20]. Введение в суспензию эритроцитов парамагнитных ионов ферицианида калия или хлористого никеля не меняло спектра ЭПР зонда 5 в мембранах, что свидетельствует о недоступности нитроксильной головки спин -меченой пальмитиновой кислоты к воде в поверхностному липидному бислою мембран эритроцитов.

Добавление СЕГ-1500 в суспензию эритроцитов заметно увеличивало микровязкость мембран эритроцитов (закон Стокса-Эйнштейна), а также значительно увеличивало параметр спектра зонда $\left.\left.5 \varepsilon=\left[\left(h_{0} / h_{+1}\right)^{1 / 2}-1\right)\right] /\left[\left(h_{0} / h_{-1}\right)^{1 / 2}-1\right)\right]$, который связывает экспериментальный параметр анизотропии спектров $(\varepsilon)$ с величиной анизотропии вращения радикала.

Таким образом, присутствие ПЭГ-1500 в суспензии эритроцитов иммобилизирует липиды в мембране эритроцитов, может значительно снизить активность мембранных ферментов, уменьшать проницаемость мембран, снижать работу ионных каналов, а также изменять ориентацию фосфолипидов мембран эритроцитов.

Ранее для изучения целостности изолированных клеток и клеток образцов тканей при любых физико-химических воздействиях нами был предложен количественный экспресс-метод оценки целых клеток с использованием метода спиновых зондов [21]. В этом методе в суспензию клеток вводят водорастворимый спиновый зонд (1), который быстро проникает внутрь клеток. Далее добавляют парамагнитный уширитель спектров ЭПР - ферицианид калия, который в норме не проникает внутрь клеток, зато расширяет до нуля (обменное взаимодействие) линии сверхтонкой структуры спектра ЭПР зонда, находящегося во внеклеточной среде. В результате этого регистрируется спектр ЭПР зонда, находящегося исключительно внутри клеток. При нарушении целостности мембран - появлению дефектов, разрывов, дыр в мембране - ферицианид калия или хлористый никель мгновенно проникает внутрь клеток и сигнал ЭПР зонда внутри клеток исчезает. Интенсивность спектра ЭПР зонда, находящегося внутри клеток, пропорциональна количеству целых клеток в суспензии (в \%). Ошибка метода в определение неповрежденных клеток не превышает 3\% [17].

Введение ПЭГ (20\%) в суспензию эритроцитов приводит к быстрому нарушению целостности мембран, проникновению парамагнитного $\mathrm{K} 3\left[\mathrm{Fe}(\mathrm{CN})_{6}\right]$ во внутриклеточную жидкость, расширению триплета зонда 1 до нуля с помощью обменного взаимодействия. Таким образом, макромолекулы ПЭГ с большой молекулярной массой при достаточных концентрациях способны разрушать даже такие прочные клетки как эритроциты (рис. 9). 


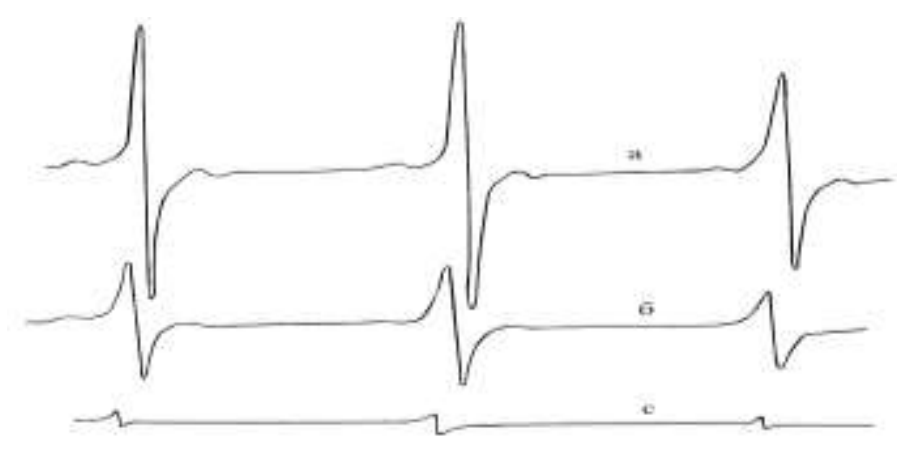

Рис. 9. Динамика нарушение изелостности мембран эритроцитов (осмотический шок) при введении ПЭГ-2000 (20\%) в суспензию эритроцитов: а - спектр ЭПР зонда 1 внутри эритроцитов (контроль), б - тот же спектр ЭПР через 10 мин., C-спектр ЭПР через 20 мин.

Конечно, эффективную локальную концентрацию ПЭГ-хвостов пегилированных липосом на соседних мембранах невозможно просчитать, и она на порядок ниже, но небольшие локальные изменения микрополярности на поверхности мембран соседних с ЛСД клеток могут расшатывать нативную структуру чужих клеток.

На рис. 10 представлены спектры ЭПР зонда 1 в внутриклеточной воде ткани кожи крысы. На рисунке видно, что в контрольном спектре ЭПР высокопольные компоненты содержит суперпозицию двух линий ЭПР с различными значениями параметра Аизо - зонд 1 находится в более и менее полярном среде (см. рис. 5), то есть во внутриклеточной среде клеток кожи находится вода с большей и меньшей полярностью.

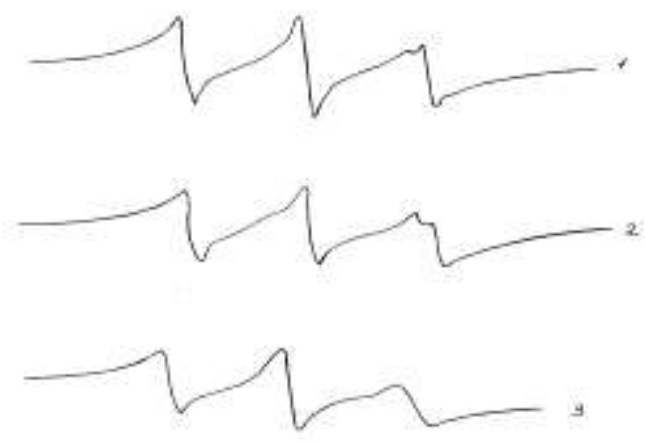

Рис. 10. Спектры ЭПР спинового зонда 1 в иитозоле клеток ткани кожи крысы: 1 - контроль; 2 - в присутствии глищерина (15\%); 3 - в присутствии ПЭГ-400 (15\%).

Введение $15 \%$ ПЭГ-400 в раствор с кусочком кожи в стеклянном капилляре в резонатор радиоспектрометра приводит к полному исчезновению более полярной и подвижной внутриклеточной жидкости, то есть к дегидратации внутриклеточной жидкости, так как ПЭГ400 осмотически активный, как и все ПЭГ. Это еще один фактор, который изменяет локальные условия среды, где могут располагаться длинные ПЭГ-хвосты пегилированных ЛСД в организме. Этот пример показывает, что даже такая жесткая ткань, как кожа реагирует на присутствие извне осмотически активных молекул ПЭГ [17].

Выводы. При наличии повышенного протромбинового индекса крови, повышенной вязкости крови и большом скоплении эритроцитов и других компонентов крови большие и длинные фрагменты молекул ПЭГ, находящихся на поверхности ЛСД, могут эффективно взаимодействовать с мембранами соседних клеток и вытеснять путем гидрофобных взаимодействий липофильные молекулы, слабо связанные с мембраной. ПЭГ-хвосты ЛСД могут также вытеснять путем гидрофобных взаимодействий липофильные молекулы из гидрофобных полостей сывороточного альбумина и ферментов крови, вызывая сбой в работе и транспорте эндогенных и экзогенных субстратов организма, а также мембранных ферментов.

Другим механизмом влияния ЛСД является повышение микровязкости мембран клеток при контакте с высокомолекулярными ПЭГ-хвостами ЛСД - торможение латеральной диффузии фосфолипидов в плоскости мембраны, которое является основным механизмом 
конформационной подвижности и функционирования липидного бислоя мембран клеток (активность мембранных ферментов, проницаемость мембран).

Следует также учитывать взаимодействие ПЭГ-хвостов ЛСД с определенными участками компонентов крови, что может вызывать частичную дегидратацию отдельных участков поверхности мембран чужих клеток с последующим локальным снижением текучести липидов мембран в месте контакта, а также снижение барьерной функции мембран вследствие увеличения проницаемости мембран в районе сорбции молекул ПЭГ.

Наличие этих возможных эффектов позволяет предположить, что расширение спектра специфической токсичности пегилированных липосом может быть прямо или косвенно связано с действием ПЭГ на белки и мембраны клеток.

\section{ЛИТЕРАТУРА}

1. Murakami T., Fan J., Yudasaka M., Iijima S., Shiba K. Solubilization of single-wall carbon nanohorns using a PEGdoxorubicin conjugate. Molecular Pharmaceutics, 2006, v.3, p.407-14.

2. Matsumura S., Ajima K., Yudasaka M., Iijima S. and Shiba K. Dispersion of Cisplatin-Loaded Carbon Nanohorns with a Conjugate Comprised of an Artificial Peptide Aptamer and Polyethylene Glycol. Molecular Pharmaceutics, 2007, v.4(5), p.723-9.

3. Клиническая фармакология. Пегилированные лекарственные препараты: современное состояние проблемы и перспективы ${ }^{\wedge}$ И.Г. Никитин, И.Е. Байкова, Л.М. Гогова, Кафедра госпитальной терапии № 2 Лечебного факультета РГМУ//Лечебное дело 4. 2005. - С.18-24.

4. Каплун А. П., Ле Банг Шон, Краснопольский Ю. М., Швец В. И. Липосомы и другие наночастицы как средство доставки лекарственных веществ // Вопросы медицинской химии. - 1999. - № 4(1). - С. 3-12.

5. Doubly radiolabeled liposomes for pretargeted radioimmunotherapy /M. Mougin-Degraef, C. Bourdeau, E. Jestin, at al.//Intern. J. Pharmaceutics. - 2007. - Vol. 344. - P. 110-117.

6. Включение изониазида в липосомы разного липидного состава/Сорокоумова Г.М., Селищева А.А., Маликова Н.М. и др.// Бюллетень экспериментальной биологии и медицины. 2004. - Т. 137. - № 1. - С.24.

7. In vitro stability and content release properties of phosphatidylglyceroglycerol contaning thermosensitive liposomes/M. Hossan, M. Wiggernhorn, A. Schwerdt et al.//Biochimica et Biophysica Acta. 2007. Vol.1768. - P. 2491-9.

8. Rohit Sood, Paav K.J. Kinnunen. Cholesterol, lanosterol and ergosterol attenuate the membrane association of LL-37 (WR7F) and temporin L// Biochimica et Biophysica Acta. 2008. - Vol.1778. - P. 1460-6.

9. Stebbing J, Gaya A. Pegylated liposomal doxorubicin (Caelyx TM) in recurrent ovarian cancer. Cancer Treat Rev 2002; 28: 121-5.

10. Pegylated liposomal doxorubicin (doxil): reduced clinical cardiotoxicity in patients reaching or exceeding cumulative doses of $500 \mathrm{mg} / \mathrm{m} 2$. / Safra T, Muggia F, Jeffers S et al.// Ann. Oncol. 2000. - Vol. 11. - P. 1029-33.

11. Безопасность комбинации карбоплатина и пегилированного липосомального доксорубицина в первой линии терапии больных раком яичников: предварительные результаты рандомизированного исследования MITO-2/S. Pignata, G. Scambia, A. Savarese et al.//Клиническая онкология. - 2007. T.2. - C.14-18.

12. Vaage J, Donovan D, Mayhew E et al. Therapy of human ovarian carcinoma xenografts using doxorubicin encapsulated in sterically stabilized liposomes. Cancer 1993; 72: 3671-75.

13. Muggia FM, Hainsworth JD, Jeffers S et al. Phase II study of liposomal doxorubicin in refractory ovarian cancer. Antitumor activity and toxicity modification by liposomal encapsulation. J Clin Oncol 1997; 15: 987-93.

14. Safra T, Groshen S, Jeffers S et al. Treatment of patients with ovarian carcinoma with pehylated liposomal doxorubicin. Analysis of toxicities and predictors of outcome. Canser 2001; 91: 90-100.

15. Зырняева Н.Н. Исследование эффективности химиотерапии экспериментальной холангиоцеллюлярной карциномы с помощью магнитоуправляемых липосом с доксорубицином: автореферат дис. ... кандидата мед. наук: 14.03.06 / Зырняева Наталья Николаевна; [Место защиты: Морд. гос. ун-т им. Н.П. Огарева]. Саранск, 2014. -22 с.

16. Липосомы в биологических системах/ Под ред. Грегориадиса Г., Аллисона А. - М.: Медицина, 1983. - 384 с.

17. Иванов Л.В., Орлова И.Н. Биофармацевтические исследования, направленные на оптимизацию состава, свойств и пути введения лекарственных препаратов. - В сб. «Технология и стандартизация лекарств», Харьков, 2000, Т. 2, с. 558-615.

18. Жданов Р.М. Парамагнитные модели биологически активних веществ М., «Наука». 1979.

19. Лихтенштейн Г.И. Метод спиновых меток в молекулярной биологии. - М.: Наука, 1974. - С. 12-24.

20. Кольтовер В.К. Спиновые метки и зонды в исследованиях модельных и биологических мембран. Итоги науки и техники. ВИНИТИ. Биофизика. 1979. - Т. II. - С. 10-100.

21. А.c. 1049808 СССР, МКИ. Способ определения степени деструкции клеток / Иванов Л.В., Моисеев В.А., Гаврилова и др. (СССР). N 3353854; Заявлено 10.11.1981; Опубл. 23.06.1983, Бюл. N 39.4 с.

22. Liposomal drug delivery systems: From concept to clinical applications /Theresa M. Allena, Pieter R. Cullis // Advanced Drug Delivery Reviews 65 (2013). 36-48. 